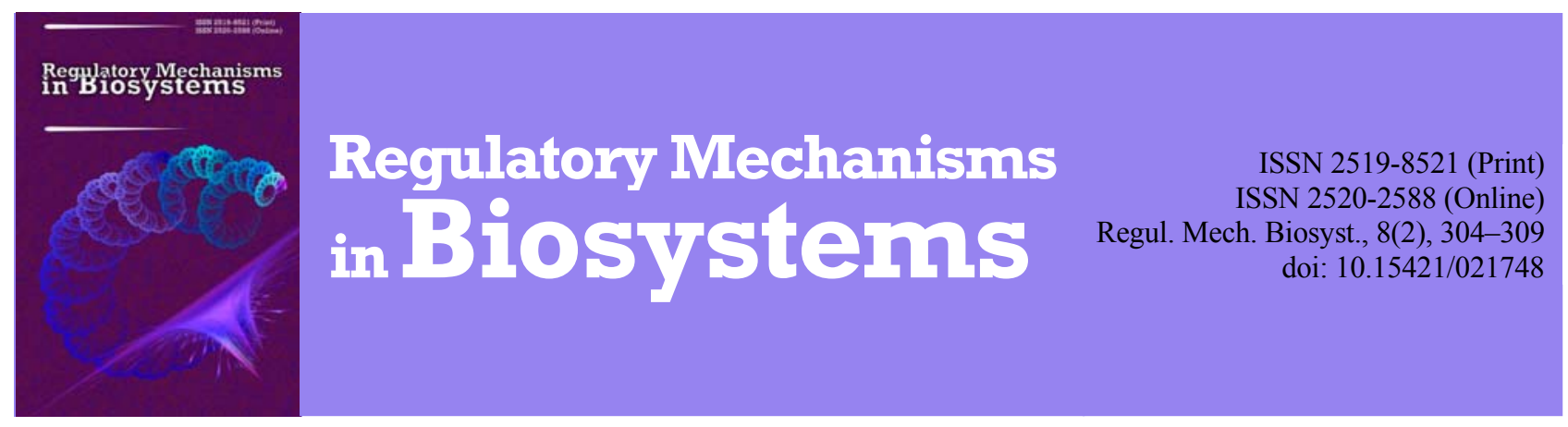

\title{
Morphological and biochemical indicators of blood of rats poisoned by carbon tetrachloride and subject to action of liposomal preparation
}

\author{
B. Gutyj*, T. Martyshchuk**, I. Bushueva***, B. Semeniv*, V. Parchenko***, A. Kaplaushenko***, \\ N. Magrelo*, A. Hirkovyy*, L. Musiy*, S. Murska* \\ *Lviv National University of Veterinary Medicine and Biotechnologies named after S. Z. Gzhytskyi, Lviv, Ukraine \\ **The Institute of Animal Biology of NAAS, Lviv, Ukraine \\ ***Zaporizhzhia State Medical University, Zaporozhye, Ukraine
}

\section{Article info}

Received 05.04.2017

Received in revised form 28.04.2017

Accepted 29.04.2017

Lviv National University of Veterinary Medicine and Biotechnologies named after S.Z. Gzhytskyi

Pekarska Str., 50,

Lviv, 79010, Ukraine.

Tel.: +38-068-136-20-54

E-mail:bvh@ukr.net

The Institute of Animal Biology of NAAS, V. Stus Str. 38 , Lviv, 79034, Ukraine.

Zaporizhzhia State Medical University, Mayakovsky Ave., 26 Zaporozhye, 69035, Ukraine.
Gutyj, B., Martyshchuk, T., Bushueva, I., Semeniv, B., Parchenko, V., Kaplaushenko, A., Magrelo, N., Hirkovyy, A., Musiy, L., \& Murska, S. (2017). Morphological and biochemical indicators of blood of rats poisoned by carbon tetrachloride and subject to action of liposomal preparation. Regulatory Mechanisms in Biosystems, 8(2), $304-309$. doi:10.15421/021748

The article gives the results of the research on the influence of a developed complex liposomal preparation on the dynamics of morphological and biochemical indicators of the blood of rats subjected to modeled oxidative stress caused by intermuscular injection of $50 \%$ carbon tetrachloride at a dose of $0.25 \mathrm{ml}$ per $100 \mathrm{~g}$ of body mass. We found that in conditions of intoxication by carbon tetrachloride, the physiological level of hematological indicators of the researched animals' body was disrupted. This is indicated by the reduction in the amount of erythrocytes, hemoglobin content, concentration of hemoglobin per erythrocyte, increase in the amount of leucocytes, mass of hemoglobin per erythrocyte and increase of colour indicator. Also, we detected suppression of protein synthesis function of the liver. The levels of total protein and albumin fraction were below the normal physiological level. High indicators were observed in the levels of creatinine, urea and total bilirubin. In order to normalize the functional state of the liver under oxidative stress it is reasonable to use a liposomal preparation which contains butafosfan, interferon, thistle and vitamins. In order to normalize morphological and biochemical indicators of the blood of rats subject to intoxication of carbon tetrachloride it is reasonable to use a liposomal preparation that contains butafosfan, selenium, thistle, methionine and vitamins. Using the liposomal preparation Butaselmevit for rats under oxidative stress the morphological and biochemical indicators in the blood normalized. On the 14th day the indictors of the number of erythrocytes, the hemoglobin content, the white blood cell count and red blood indexes compared to control came within the physiological indicators, indicating a recovery of hematopoietic function of the bone marrow and normalized indicators of the functional state of the liver.

Keywords: carbon tetrachloride; liver; Butaselmevit; butafosfan; selenium; milk thistle; vitamins, methionine

\section{Introduction}

The intensive introduction of chemical preparations into industry and agriculture, deterioration of the environment, pollution of the environment with xenobiotics, uncontrolled usage of medicines cause an increase of toxic effects in human and animal organisms ( $\mathrm{Li}$ et al., 2012; Gutyj et al., 2017). It is known that the central organ which conducts the detoxification processes of organisms is the liver (Calabrese et al., 1999; Cherkashina and Petrenko, 2006). Among diffuse liver diseases, great attention is paid to toxic affections of the liver (Sato et al., 1999; Yatsenko and Maloshtan, 2004). Recently, the role in pathogenesis of liver diseases played by processes of activation of free radical oxidation of lipids (FROL) plasmatic and intracellular membranes of hepatocytes against the background of the depletion of protective antiradical systems has been determined (Gutyj et al., 2016).

Poisoning experimental animals with carbon tetrachloride provides a close approximation according to the morphological picture and biochemical changes to acute affection of the liver of different etiology in humans and animals. Owing to this, we used in our work the classic model of affection of subcellular membranes of hepatocytes and induction of oxidative stress through the use of carbon tetrachloride. Through this, as a result of metabolism of $\mathrm{CCl}_{4}$, products of a free radical nature which are inductors of lipid peroxidation (POL) are created in the organism, as a result of which the structure of liver cells and their major functions is disrupted (Calabrese et al., 1999; Chen et al., 2000; Cherkashina and Petrenko, 2006; Vyshtakaliuk et al., 2015).

In order to increase the adaptive capability and immune biological reactivity of the organism, the strengthening of protein synthesis and enzyme function in animals, new complex preparations have recently been used with success (Gutyj et al., 2016, 2017; Hariv and Gutyj, 2016; Martyshuk et al., 2016; Smolynets' et al., 2016). Some other authors have determined the stimulating influence of milk thistle, vitamins, selenium and butafosfan on the activity of antioxidant and hepatoprotective action in animals (Martyshuk et al., 2016; Khariv et al., 2016). However, complex usage of the abovementioned preparation on the function of the liver and hematological indicators currently in scientific literature has not been adequately researched.

This shows that it is reasonable to research the influence of the complex liposomal preparation Butaselmevit which include butafosfan, selenium, methionine, vitamins and milk thistle on the development of immunity and of high natural resistance in animals, their influence on the liver functions, positive influence on metabolism in their organism, increase of growth and preserving the population of animals. 


\section{Materials and methods}

The research was carried out on young white laboratory male rats of the Wistar line and of body mass - 180-200 g, which were reared in standard conditions in the institutional vivarium of the State Scientific-Research Control Institute of Veterinary Preparations and Feed Additives. During the whole experiment the rats were fed with a balanced ration that included all necessary components, drinkable water was given to the animals without any restriction from glass drinkers of 0.2 liters volume.

The animals were divided into three groups with 20 animals in each: 1st group $(C)$ intact animals; 2 nd $\left(D_{1}\right)$ rats that were affected with carbon tetrachloride; 3 rd group $\left(\mathrm{D}_{2}\right)$ - rats affected with carbon tetrachloride and treated with the liposomal preparation Butaselmevit. The toxic affection of rats was caused by means of intramuscular injection of $50 \%$ carbon tetrachloride in dose of $0.25 \mathrm{ml}$ per $100 \mathrm{~g}$ body mass on the first and third day of the experiment. The animals of the research group $\mathrm{D}_{2}$, additionally were injected with a liposomal preparation in dose $2 \mathrm{ml}$ per $1 \mathrm{~kg}$ of body mass on the first and third days of the experiment an hour after injection of carbon tetrachloride. The content of this preparation has the following elements: butafosfan, selenium, methionine, thistle and vitamins $\mathrm{A}, \mathrm{E}$ and $\mathrm{D}_{3}$.

Blood for biochemical and hematological researches was collected under ether anesthesia from the jugular vein on the second, fifth, tenth and fifteenth days of the experiment.

Housing, feeding, looking after and all other manipulations with animals were done according to the European Convention for the Protection of Vertebrate Animals used for Experimental and Other Scientific Purposes (Strasbourg, 1986) and General Ethical Principles of Experiments on Animals, adopted by the First National Bioethics Congress (Kyiv, 2001). The experiments were conducted in accordance with the principles of humanity set out in the Directive of the European Community.

The amount of erythrocytes and leucocytes was counted on the Goryaev camera according to generally recognizable method. The level of blood hemoglobin was determined by the cyanide hemoglobin method with the usage of FEK-M according to the method of H. V. Derviz and A. H. Vorobiov. The amount of hematocrit was determined by blood centrifugation in micropipettes $3000 \mathrm{rpm}$. According to the number of erythrocytes, hemoglobin level and amount of hematocrit, according to the corresponding formula, using the method of mathematical calculations, the following indexes of indicators of red blood were determined: the average volume of one erythrocyte (MSV), the average weight of hemoglobin (MSN), the average hemoglobin concentration (MSNS), the colour index (KP) (Vlizlo, 2012).

The analysis of the research results were conducted using the program Statistica 6.0. The reliability of the difference was evaluated by Student's t-test. The results were considered significant at $\mathrm{P}<$ 0.05 .

\section{Results}

The importance of the clinical-diagnostic research of blood lies in the fact that through tissue fluid it secures direct connection between organs and tissues and reflects the internal processes and changes in an organism and in pathological conditions it can have qualitative and quantitative changes.

The results of the hematological indicators research of the organism of rats poisoned with carbon tetrachloride and subject to the action of the liposomal preparation Butaselvemit are presented in Table 1. It was found that after the development of oxidation stress in rats, caused by the injection of carbon tetrachloride (research group 1), these indicators were different from the indicators of the control group of animals. This was caused due to the negative effect of carbon tetrachloride on the function of erythrocyte production in the bone marrow of rats.

On the second day in the blood of rats of the first research group we found a decrease in the number of erythrocytes by $32.7 \%$ $(\mathrm{P}<0.001)$ in comparison with the control group. The level of hemoglobin in the blood decreased from $149.6 \pm 1.6$ to $122.3 \pm$ $2.3 \mathrm{~g} / 1$, that is $18.2 \%$ lower $(\mathrm{P}<0.001)$ than in the clinically healthy animals. It is known that the level of hemoglobin is in direct dependence on the number of erythrocytes. However, as it is shown in the table, in rats of the research group $\mathrm{D}_{1}$ poisoned with carbon tetrachloride the amount of erythrocytes decreased by $32.7 \%$ and the level of hemoglobin in blood decreased by $18.2 \%$. This was caused by the erythrocyte hemolysis under the action of carbon tetrachloride. The non-proportional decrease of the amount of erythrocytes and decrease of the hemoglobin level in the blood is explained by the fact that in connection with a decrease in the total number of erythrocytes inside the bloodstream young erythrocytes appeared, which had a large volume and therefore greater weight of hemoglobin, compared with the old erythrocytes with less volume. However, the concentration of hemoglobin in young erythrocytes was lower than in the old ones.

The decrease of the amount of erythrocytes and hemoglobin in blood of rats under oxidative stress indicates the suppressed function of erythrocyte production in the bone marrow of rats as a result of the action of carbon tetrachloride.

The hematocrit value indicates the relation between formed elements and blood plasma. After the injection into rats of the research group $\mathrm{D}_{1}$ of carbon tetrachloride, the amount of hematocrit on the 2nd day of the research increased to $32.7 \pm 1.37 \mathrm{vol} \%$.

On the basis of the indicators of the erythrocyte count, the content of hemoglobin in the blood and amount of hematocrit, one cannot objectively evaluate the hematopoietic function of the bone marrow. In order to do this, one must determine the value of indexes of red blood: average volume of one erythrocyte $(\mathrm{MCV})$, an increase of which (macrocytosis) is an indicator of moderate erythrocytosis. The average mass of hemoglobin in an erythrocyte $(\mathrm{MCH})$ can be high in cases of hemolytic and myelotoxic anemia. The average concentration of hemoglobin in an erythrocyte (MCHC) increases after hyperchromic anemia and decreases with the occurrence of ferrum deficit anemia. The increase in its concentration indicates the presence in the blood of "young" erythrocytes with a high content of hemoglobin and decrease indicates presence of "old" erythrocytes with low content of hemoglobin.

We found that in case of poisoning with carbon tetrachloride the average mass of hemoglobin in one erythrocyte is $21.6 \%$ greater and its average concentration $29.7 \%$ lower than in clinically healthy animals. Such discrepancy between mass and concentration of hemoglobin in a single erythrocyte is caused by the fact that young erythrocytes are present in the blood, the average volume of which exceeds physiological indicators. The presence in rats of the control group $\mathrm{D}_{1}$ of young blood elements with a large mass of hemoglobin caused changes in the colour indicator quantity. Clinically healthy animals had $0.69 \pm 0.04 \mathrm{IU}$ and under oxidative stress $-0.84 \pm 0.05 \mathrm{IU}$.

When there were inflammation processes in the organism of rats which were injected with carbon tetrachloride we observed an increase in the number of leucocytes, which on the second day increased by $59 \%$ in the blood of research group $D_{1}$. The highest amount of leucocytes in the blood of sick rats was on the fifth day of research, increasing almost 1.2 times compared to the control group.

It should be noted that on the 5th and 10th day of the research, the hematological indicators of the blood of rats in the first research group which were injected with carbon tetrachloride did not change significantly compared to the samples that were taken on the 2nd day of the research.

On the 14th day of the research the number of erythrocytes in rats of the research group $\mathrm{D}_{1}$ was lower by $33 \%$ and the level of hemoglobin higher by $8 \%$ compared with the indicators of the control group of animals $(\mathrm{P}<0.01)$. Indicators which were quite high on the 14th day of research in the first experimental group were as follows: the number of erythrocytes was higher by $67 \%$, hematocrit by $19 \%$, mass of hemoglobin by $38 \%$, volume of erythrocytes by $78 \%$, colour indicator by $37 \%$, however the concentration of hemoglobin was lower by $22 \%$ compared to the indicators of the control group, which indicates the suppressed erythropoietic function in the bone marrow at 
that period of the research.

As has been shown in our research and the work of other authors, erythrocytes had a higher mass of hemoglobin as a result of the increase of average volume of one erythrocyte. However, the average concentration of hemoglobin in such erythrocyte was lower than normal, which led to hypochromia. This compensatory reaction of the organism developed as a result of hypoxia of the tissue, which was caused by the decrease of total number of erythrocytes. It is aimed at setting the optimal level of hemoglobin for total usage of its functional possibilities. It is generally known that with a lower concentration of hemoglobin per erythrocyte, its ability to bind oxygen is relatively higher. This is plays a positive role in securing transporting of oxygen to the tissues.

According to the data in the literature changes in the morphological indicators of the blood are closely connected with the dysfunction of erythropoietic function of the bone marrow (Wolf, 1999; Sato et al., 1999; Longo et al., 2007). The experiments conducted indicate that animals under the intoxication with carbon tetrachloride undergo suppression of haematopoiesis of the bone marrow. This was indicated by the decrease in the number of erythrocytes and decrease in the level of hemoglobin in the blood. Following decrease in the number of erythrocytes and decrease in the level of hemoglobin in the blood, tissue hypoxia occurs. This slows down the oxidative-reduction processes and leads to deteriorating metabolism in the tissues.

Recently in order to prevent the manifestations of intoxication of the liver, increasing use has been made of antioxidant preparations to correct the system of antioxidant protection and for neutralization of free radical oxidation products. The search for active substances with antioxidant properties is quite promising area of research, though it requires taking into account problems of compatibility of natural and synthetic antioxidants. The key factor of antioxidant action of a preparation is total amount of antioxidant substances in its content, the qualitative anti- oxidant spectrum (vitamins, vitamin-like substances, microelementsmetals) and also total quantitative content of substances with antioxidant features. Under intoxication with carbon tetrachloride and using Butaselmevit liposomal preparation, we observed the normalization of hematological indicators among rats of the second experimental group $\left(D_{2}\right)$ throughout the period of research. Particularly on the 5th and 10th day of research we observed reliable increase in the number of erythrocytes $5.86 \pm 0.11$ and $6.21 \pm 0.12 \mathrm{~T} / 1$ respectively. However in comparison with the control group of animals it was lower by $9 \%$ and $4 \%$. In the abovementioned period of research we determined an increase in the level of hemoglobin, which indicates gradual normalization of the hematopoietic function of the bone marrow of the rats which received the liposomal preparation and which suffered intoxication with carbon tetrachloride.

The recovery of hematopoietic function of the bone marrow of rats intoxicated with carbon tetrachloride and receiving the liposomal preparation is explained by the fact that Butaselmevit contains Silybum marianum. The fruits of the milk thistle contain high levels of vitamins $\mathrm{A}$ and $\mathrm{C}$ and minerals - cobalt, iron, copper, which are directly involved in the process of hematopoiesis. Secondly, the fruits of the milk thistle contain Silymarin flavolignans. The hepatoprotective effect of Butaselmevit and improvement of liver detoxification function reduces or prevents irritation caused by toxins which enter the bodies of animals.

It should be noted that on the 5th and 10th days of the research after injecting liposomal preparation to rats of the second research group in conditions of oxidative stress, a decrease in the number of leucocytes occurred. However, this indicator was still high, in particular on the 5th day higher by $58 \%$, on the 10 th day higher by $35 \%$ than the level of this indicator for the control group. On the 14th day of the experiment, the number of leucocytes in the' blood of the rats of research group $\mathrm{D}_{2}$ was within the physiological norms.

\section{Table 1}

Morphological indicators of blood of rats intoxicated with carbon tetrachloride and receiving the liposomal preparation Butaselmevit $(\mathrm{M} \pm \mathrm{m} ; \mathrm{n}=20)$

\begin{tabular}{|c|c|c|c|c|c|}
\hline \multirow{2}{*}{ Indicator } & \multirow{2}{*}{$\begin{array}{l}\text { Research } \\
\text { group }\end{array}$} & \multicolumn{4}{|c|}{ Day of research } \\
\hline & & second & fifth & tenth & fourteenth \\
\hline \multirow{3}{*}{ Erythrocytes, T/1 } & $\mathrm{C}$ & \multicolumn{4}{|c|}{$6.44 \pm 0.151$} \\
\hline & $\mathrm{D}_{1}$ & $4.33 \pm 0.120 * * *$ & $4.37 \pm 0.095^{* * *}$ & $4.27 \pm 0.055 * * *$ & $4.30 \pm 0.095 * * *$ \\
\hline & $\mathrm{D}_{2}$ & $5.87 \pm 0.111^{*}$ & $5.86 \pm 0.110^{*}$ & $6.21 \pm 0.124$ & $6.21 \pm 0.195$ \\
\hline \multirow{3}{*}{ Hemoglobin, g/l } & $\mathrm{C}$ & \multicolumn{4}{|c|}{$149.6 \pm 1.58$} \\
\hline & $\mathrm{D}_{1}$ & $122.3 \pm 2.25 * * *$ & $139.1 \pm 2.11^{* *}$ & $140.8 \pm 0.85 * *$ & $137.9 \pm 1.45^{*}$ \\
\hline & $\mathrm{D}_{2}$ & $146.9 \pm 1.89$ & $149.1 \pm 1.66$ & $148.7 \pm 1.62$ & $151.6 \pm 2.62$ \\
\hline \multirow{3}{*}{ Leucocytes, G/1 } & $\mathrm{C}$ & \multicolumn{4}{|c|}{$9.4 \pm 0.85$} \\
\hline & $\mathrm{D}_{1}$ & $14.9 \pm 0.83 * *$ & $20.8 \pm 1.56 * * *$ & $20.0 \pm 1.44 * *$ & $15.6 \pm 1.92 *$ \\
\hline & $\mathrm{D}_{2}$ & $15.1 \pm 1.48^{*}$ & $14.8 \pm 1.59 *$ & $12.6 \pm 1.63$ & $9.9 \pm 1.52$ \\
\hline \multirow{3}{*}{ Quantity of hematocrit, vol\% } & $\mathrm{C}$ & \multicolumn{4}{|c|}{$28.1 \pm 0.75$} \\
\hline & $\mathrm{D}_{1}$ & $32.7 \pm 1.37 * * *$ & $32.3 \pm 1.65$ & $32.5 \pm 1.41 *$ & $33.3 \pm 1.56^{*}$ \\
\hline & $\mathrm{D}_{2}$ & $31.6 \pm 1.26$ & $29.2 \pm 1.05$ & $28.7 \pm 0.95$ & $28.5 \pm 1.05$ \\
\hline \multirow{3}{*}{ Volume of erythrocyte, $\mu \mathrm{m}^{3}$} & $\mathrm{C}$ & \multicolumn{4}{|c|}{$43.6 \pm 1.15$} \\
\hline & $\mathrm{D}_{1}$ & $75.5 \pm 1.22 * * *$ & $73.9 \pm 1.31 * * *$ & $76.1 \pm 1.20 * * *$ & $77.4 \pm 1.23 * * *$ \\
\hline & $\mathrm{D}_{2}$ & $53.8 \pm 1.15^{* * *}$ & $49.8 \pm 1.16^{* *}$ & $46.2 \pm 1.19$ & $45.8 \pm 1.15$ \\
\hline \multirow{3}{*}{$\begin{array}{l}\text { Mass of hemoglobin in } \\
\text { erythrocyte, pg }\end{array}$} & $\mathrm{C}$ & \multicolumn{4}{|c|}{$23.2 \pm 1.54$} \\
\hline & $\mathrm{D}_{1}$ & $28.3 \pm 1.33 *$ & $31.8 \pm 1.34 * *$ & $32.9 \pm 1.36^{* *}$ & $32.1 \pm 1.40^{* *}$ \\
\hline & $\mathrm{D}_{2}$ & $25.0 \pm 1.35$ & $25.4 \pm 1.50$ & $23.9 \pm 1.50$ & $24.4 \pm 1.50$ \\
\hline \multirow{3}{*}{$\begin{array}{l}\text { Concentration of hemoglobin } \\
\text { in erythrocyte, } \%\end{array}$} & $\mathrm{C}$ & \multicolumn{4}{|c|}{$53.2 \pm 1.35$} \\
\hline & $\mathrm{D}_{1}$ & $37.4 \pm 1.41^{* * *}$ & $43.1 \pm 1.37 * *$ & $43.3 \pm 1.35^{* *}$ & $41.4 \pm 1.40^{* * *}$ \\
\hline & $\mathrm{D}_{2}$ & $46.5 \pm 1.39 *$ & $51.1 \pm 1.39$ & $51.8 \pm 1.36$ & $53.9 \pm 1.38$ \\
\hline \multirow{3}{*}{ Colour indicator } & $\mathrm{C}$ & \multicolumn{4}{|c|}{$0.69 \pm 0.041$} \\
\hline & $\mathrm{D}_{1}$ & $0.84 \pm 0.051$ & $0.95 \pm 0.039 * *$ & $0,98 \pm 0,053^{* *}$ & $0.95 \pm 0.052 * *$ \\
\hline & $\mathrm{D}_{2}$ & $0.81 \pm 0.043$ & $0.79 \pm 0.044$ & $0,78 \pm 0,040$ & $0.77 \pm 0.043$ \\
\hline
\end{tabular}

Note: the degree of probability: * $-\mathrm{P}<0.05 ; * *-\mathrm{P}<0.025 ; * * *-\mathrm{P}<0,001$.

When the liposomal preparation Butaselmevit was administered to rats of the research group $\mathrm{D}_{2}$ on the 2 nd day of research the following indicators were within the physiological values: value of hematocrit, hemoglobin mass and hemoglobin concentration. However, the large average volume of one erythrocyte $51.2 \pm 1.19$ against $43.7 \pm$ $1.16 \mu \mathrm{m}^{3}$ indicates the incomplete restoration of hemopoetic function of the bone marrow.

On the tenth day of the experiment on rats under oxidative stress and receiving liposomal preparation hematopoietic function of bone marrow was not restored totally. However, within this period the following indicators were within the physiological values: value of hematocrit, hemoglobin mass and hemoglobin concentration. However, the large average volume of one erythrocyte $46.2 \pm 1.19$ against $43.6 \pm$ $1.15 \mu \mathrm{m}^{3}$ indicates the incomplete restoration of hematopoietic function of bone marrow.

On the 14th day of the experiment on sick rats using the lipo- 
somal preparation we noticed the normalization in the number of erythrocytes, leucocytes and the level of hemoglobin. The values of indexes of red blood were within the physiological frames. These changes in the blood indicators show that hematopoietic function of bone marrow was totally restored by the 14th day of research.

Thus, on the basis of the experiments conducted we should note the positive action of liposomal preparation Butaselmevit on the organism of rats which were intoxicated with carbon tetrachloride, which was manifested in the normalization of the rats' hematological indicators.

Protein is considered to be the major element on which the internal processes of organism construction are based. It supports the flow of blood, its viscosity and determines the necessary volume of blood to flow in the vessel. Due to proteins, forming elements are held in hanging position and also the transportation of the most important exogenous and endogenous substances takes place. Owing to proteins, the level of $\mathrm{pH}$ in blood is regulated. Proteins take an active part in immune reactions.

Most protein is synthesized directly in the liver. Hepatocytes synthesize albumin and fibrinogen, alpha and beta globulins, and components of blood coagulation. Most beta-globulin is synthesized directly in the cells-lymphocytes.

The level of total protein, in particularly its albumin fraction in the blood serum of animals suffering various pathological conditions, indicates the state of protein synthesizing function of the liver. Indeed, $80 \%$ of albumin is synthesized by hepatocytes in the liver.

Our research (Table 2) showed that in conditions of oxidative stress in rats of the research group $D_{1}$ the level of total protein probably decreased on the second day of the experiment when it was $58.8 \pm 1.75 \mathrm{~g} / \mathrm{l}$, meanwhile in control group of animals it was $65.3 \pm$ $1.80 \mathrm{~g} / \mathrm{l}$. On the 5th, 10th and 14th days of the experiment the level of this indicator rose slightly, but in comparison with the control group of animals it was reduced. The decrease of the level of total protein occurred owing to the decrease of albumin fraction. So, on the second day of the experiment the level of albumin in the blood of rats of the research group $\mathrm{D}_{1}$ decreased by $41 \%$ and on the 5 th day by $44 \%$ compared to the indicators of the animals of the control group.

Along with the reduction of albumins in the blood serum of the sick rats, we observed a slight rise in the globulin fraction, on the 2 nd and 5 th days of the experiment the level of globulins rose by $7 \%$ and $6 \%$. Subsequently, the level of globulins remained the same as on the 5 th day of the experiment.

The experimental data indicate an albumin-globulin disproportion in the blood serum of the sick rats. As a result, the value of $\mathrm{A} / \mathrm{G}$ coefficient on the 2nd day of the experiment was $0.29 \pm 0.02$ against $0.53 \pm 0.02$ in the control group of rats. Such value of coefficient indicates the suppression of protein synthesizing function of the liver.

While the liposomal preparation Butaselmevit was administered to rats of the experimental group $\mathrm{D}_{2}$ intoxicated with carbon tetrachloride, we determined a rise in the level of total protein and albumin fraction and decrease in the globulin level in blood serum of the rats on the 2nd and 5th days of the experiment. On the 10th and 14th days of the experiment we observed in rats of the second research group a normalization of indicators of protein synthesis function of the liver. The $A / G$ coefficient also remained within the frame of physiological values.

Table 2

Indicators of functional state of liver of rats under conditions of oxidative stress and receiving liposomal preparation $(\mathrm{M} \pm \mathrm{m} ; \mathrm{n}=20)$

\begin{tabular}{|c|c|c|c|c|c|}
\hline \multirow{2}{*}{ Indicator } & \multirow{2}{*}{ Research group } & \multicolumn{4}{|c|}{ Day of research } \\
\hline & & second & fifth & tenth & fourteenth \\
\hline & $\mathrm{C}$ & \multicolumn{4}{|c|}{$65.3 \pm 1.80$} \\
\hline \multirow[t]{3}{*}{ Total protein, $\mathrm{g} / \mathrm{l}$} & $\mathrm{D}_{1}$ & $59.1 \pm 1.33^{*}$ & $57.9 \pm 2.05^{*}$ & $60.2 \pm 1.95$ & $62.4 \pm 2.10$ \\
\hline & $\mathrm{D}_{2}$ & $58.8 \pm 1.75$ & $62.9 \pm 1.08$ & $64.6 \pm 0.87$ & $66.4 \pm 1.23$ \\
\hline & $\mathrm{C}$ & \multicolumn{4}{|c|}{$22.6 \pm 1.25$} \\
\hline \multirow[t]{3}{*}{ Albumins g/l } & $\mathrm{D}_{1}$ & $13.3 \pm 1.60^{* *}$ & $12.7 \pm 2.22 * *$ & $14.9 \pm 1.90^{*}$ & $17.6 \pm 1.85$ \\
\hline & $\mathrm{D}_{2}$ & $14.1 \pm 1.92 * *$ & $18.9 \pm 1.35$ & $21.1 \pm 1.55$ & $22.7 \pm 0.83$ \\
\hline & $\mathrm{C}$ & \multicolumn{4}{|c|}{$42.7 \pm 1.41$} \\
\hline \multirow[t]{3}{*}{ Globulins, g/l } & $\mathrm{D}_{1}$ & $45.8 \pm 2.23$ & $45.2 \pm 2.63$ & $45.3 \pm 1.75$ & $44.8 \pm 2.23$ \\
\hline & $\mathrm{D}_{2}$ & $44.7 \pm 1.82$ & $44.0 \pm 2.20$ & $43.5 \pm 1.60$ & $43.7 \pm 1.70$ \\
\hline & $\mathrm{C}$ & \multicolumn{4}{|c|}{$0.53 \pm 0.023$} \\
\hline \multirow[t]{3}{*}{ Coefficient, A/G } & $\mathrm{D}_{1}$ & $0.29 \pm 0.021 * * *$ & $0.28 \pm 0.030^{* * *}$ & $0.33 \pm 0.039^{* *}$ & $0.39 \pm 0.034^{*}$ \\
\hline & $\mathrm{D}_{2}$ & $0.32 \pm 0.026^{* * *}$ & $0.43 \pm 0.038$ & $0.49 \pm 0.027$ & $0.52 \pm 0.037$ \\
\hline & $\mathrm{C}$ & \multicolumn{4}{|c|}{$66.3 \pm 2.56$} \\
\hline \multirow[t]{3}{*}{ Creatinine, $\mu \mathrm{mol} / 1$} & $\mathrm{D}_{1}$ & $96.5 \pm 3.22 * * *$ & $95.2 \pm 4.35^{* *}$ & $88.5 \pm 3.37^{* *}$ & $81.7 \pm 3.50^{*}$ \\
\hline & $\mathrm{D}_{2}$ & $94.9 \pm 3.75^{* * *}$ & $84.9 \pm 3.76^{* *}$ & $72.8 \pm 2.84$ & $68.9 \pm 3.87$ \\
\hline & $\mathrm{C}$ & \multicolumn{4}{|c|}{$6.6 \pm 0.91$} \\
\hline \multirow[t]{3}{*}{ Urine, $\mu \mathrm{mol} / 1$} & $\mathrm{D}_{1}$ & $11.5 \pm 1.71^{*}$ & $10.9 \pm 1.23^{*}$ & $10.0 \pm 1.14$ & $9.2 \pm 0.58$ \\
\hline & $\mathrm{D}_{2}$ & $11.1 \pm 1.37^{*}$ & $9.0 \pm 0.75$ & $7.8 \pm 0.63$ & $6.5 \pm 0.90$ \\
\hline & $\mathrm{C}$ & \multicolumn{4}{|c|}{$3.9 \pm 0.57$} \\
\hline \multirow[t]{2}{*}{ Total bilirubin, $\mu \mathrm{mol} / 1$} & $\mathrm{D}_{1}$ & $5.2 \pm 0.73$ & $5.0 \pm 0.66$ & $4.6 \pm 0.93$ & $4.5 \pm 0.65$ \\
\hline & $\mathrm{D}_{2}$ & $4.8 \pm 0.65$ & $4.4 \pm 0.85$ & $4.1 \pm 0.51$ & $3.9 \pm 0.71$ \\
\hline
\end{tabular}

Note: the degree of probability: $*-\mathrm{P}<0.05 ; * *-\mathrm{P}<0.025 ; * * *-\mathrm{P}<0.001$.

The functional state of the liver of rats intoxicated with carbon tetrachloride was determined according to the level of urine, bilirubin and creatinine in the blood serum (Table 2).

The important indicator of the functional state of liver is the level of urine in blood serum, since its synthesis is taking part on periportal hepatocytes. The liver is an organ in which the main amount of ammonia is neutralized. Up to $85 \%$ of ammonia that is formed in an animal's intestine is converted to urine in the liver. Moreover, the more ammonia enters a liver, the more urine is formed which is indicated by its level in the blood serum.

We found that on the 2nd day of the experiment the level of urine in the blood serum of rats of the group $\mathrm{D}_{1}$ level was $11.5 \pm 1.71 \mu \mathrm{mol} / \mathrm{l}$. On the 5 th day this indicator decreased to $10.9 \pm 1.23 \mu \mathrm{mol} / \mathrm{l}$. On the 10th day of the experiment the level of urine in blood serum of the sick rats decreased to $10.0 \pm 1.14 \mu \mathrm{mol} / \mathrm{l}$, which was $52 \%$ higher than the indicators of the rats of the control group. The content of urine in the blood serum of the sick rats was on the same level on the 14th day of the experiment.

In the experiment on the influence of the liposomal preparation Butaselmevit on the organism of rats intoxicated with carbon tetrachloride, we found that the level of urine in the blood serum of rats of the research group $\mathrm{D}_{2}$ on the 2 nd day of the experiment was $11.1 \pm$ $1.37 \mu \mathrm{mol} / \mathrm{l}$. By the 5 th and 10th days of the experiment the level of urine in the blood serum of the researched rats had gradually decreased, however compared to the control group of animals it was higher by $36 \%$ and $18 \%$. On the 14th day of research the level of urine was within the physiological values.

An important function of the liver is its participation of pigment exchange in metabolism processes. This function of the liver is identified according to the level of total bilirubin in the blood serum. In disorders of the pigmentary function of the liver, there is a decrease in absorption, conjugation and excretion of bilirubin in the bile, leading to increase in its level in blood serum.

In our experiments we found that in rats intoxicated with carbon 
tetrachloride, the level of total bilirubin in blood serum on the 2nd day of the experiment increased by $34 \%$ and on the 5 th day by $29 \%$ compared to the control. Such high levels of total bilirubin were reached in the blood serum of rats of the experimental group $D_{1}$ on the 10th and 14th days of the experiment.

Creatinine is the final product of nitrogen metabolism. It is created in muscle tissue out of phosphocreatine. The level of creatinine in blood serum is the indicator of renal excretory function. In rats of the experimental group $\mathrm{D}_{1}$, the content of creatinine blood in serum from the second to the fourteenth day of the experiment was within $96.5-$ $81.7 \mu \mathrm{mol} / \mathrm{l}$. While studying the action of the liposomal preparation in rats of the second research group which were injected with carbon tetrachloride, we noticed the normalization of the level of creatinine indicators and total bilirubin on the 5th and 10th days of the experiment. On the 14th day of the research these indicators were within the physiological values.

Thus, on the basis of our experiment the positive action of the liposomal preparation Butaselmevit on the organism of rats which were intoxicated with carbon tetrachloride was manifested by the normalization of hematological indicators, functional state and protein synthesis function of the liver.

\section{Discussion}

According to the data of morphological study of the liver of rats poisoned by carbon tetrachloride, a strong intensification of free radical processes was found. In their research the authors (Gutyj et al., 2016; Lavryshyn et al., 2016) found a relation between the indicators of antioxidant protection and expression of destructive changes of hepatocytes or degree of development of toxic hepatosis. Such suppression of elements of the antioxidant protection system is probably caused by their exhaustion as a result of the intensification of POL under the influence of carbon tetrachloride and also the disruption of their synthesis, caused by the destruction of membrane components of the granular and agranual endoplasmic reticulum, free ribosomes and polysomes of hepatocytes cytoplasm.

It was determined that acute toxic affection of the liver of rats poisoned with carbon tetrachloride causes the malfunction of structural and functional activity of hepatocytes. As a result of destruction of membrane and protein components of hepatocytes, caused by the extraction of hepatotoxins, substantial changes were observed in the indicators of protein metabolism - total protein, urine, protein fractions. Thus, the content of total protein in the blood serum increased and in the liver tissue it decreased 1.2 times.

Some authors (Chen et al., 2000; Martyshuk et al., 2016; Khariv et al., 2016) state that the toxic action of carbon tetrachloride on the liver is also accompanied by the violation of its functional state, which is characterized by the accumulation of aminotransferase in the blood serum of laboratory animals. According to data from the literature, the increase in the activity of these enzymes following liver affection is closely correlated with the stage of hepatocytes' destructtion (Wolf, 1999; Sato et al., 1999; Longo et al., 2007). A decrease in activity of the enzyme system of antioxidant protection in the kidneys of rats following the injection of carbon tetrachloride has also been mentioned by other authors as well (Khariv et al., 2016).

Experiments to determine the resistance capacity of erythrocytes have shown that the influence of carbon tetrachloride on the organism of animals causes the increase of permeability of erythrocyte membranes and is followed by an increase in the level of hemolysis of erythrocytes.

The results of the research and data from the literture allow us to draw the conclusion that the decrease of resistance of erythrocytes in animals with acute and chronic intoxication with carbon tetrachloride is connected with oxidative damage to hepatocytes membranes (Gutyj et al., 2016; Khariv et al., 2016). The toxic action of carbon tetrachloride damages the cell membranes, which is followed by their structural and functional changes. During the process of biological transformation, reactive intermediates are created which damage the liver tissue. In hepatocytes the molecule $\mathrm{CCl}_{4}$ take part in the reaction of hemolytic disintegration in interaction in the liver with cytochrome enzyme P-450 to create the reactive free radicals ${ }^{\circ} \mathrm{CCl}_{3}$ and ${ }^{\circ} \mathrm{C} 1$ (Martyshuk et al., 2016). Free radicals influence the functional group of proteins and initiate a chain reaction of peroxide oxidation of polyunsaturated fatty acids, which leads to the disintegration of polysomes, ribosomes. Thus, obtained results of the experiment indicate that in the blood of rats intoxicated with carbon tetrachloride an intensification of free radical processes was observed in the hepatocytes and in the blood, which led to the activation of the processes of lipid peroxidation and accumulation of endogenous toxic products, which caused the violation of morphological and biochemical indicators of the rats' blood.

The usage of the liposomal preparation Butaselmevit promoted the normalization of both, morphological and biochemical indicators of the blood of rats poisoned with carbon tetrachloride. The liposomal preparation Butaselmevit suppressed processes of lipid peroxidation, perhaps due to the fact that the preparation includes two powerful antioxidants such as vitamin $\mathrm{E}$ and selenium, which in turn reinforce each other's action. The antioxidant peculiarities of the milk thistle should also be emphasized, which according to the data from the literature possesses precisely this property. Its content include vitamins of group B, A, E, K, precursors of vitamin D, carotenoids, macroelements - potassium, calcium, magnesium, iron and microelements - copper, zinc, manganese, iodine. The total effect of these biologically important elements is manifested in a high level of hepatoprotective and antioxidant action (Khariv et al., 2016).

\section{Conclusions}

The hematopoietic function of bone marrow is violated in rats subject to intoxication with carbon tetrachloride, which can be observed in the decrease in the amount of erythrocytes by $34 \%$, content of hemoglobin by $18 \%$, concentration of hemoglobin per erythrocyte by $30 \%$, increase of the mass of hemoglobin per erythrocyte by $38 \%$, increase in volume of erythrocyte by $77 \%$, increase in colour indicator by $42 \%$. The development of oxidative stress in rats was caused by intramuscular injection of carbon tetrachloride, which was followed by the suppression of protein synthesis function of the liver, which is indicated by the low level of total protein and decrease in the albumin-globulin coefficient. The low level of albumins and high level of globulins in the blood of the sick rats indicates an albuminglobulin disproportion. Indicators of the functional state of liver were fairly high, namely: the level of creatinine increased by $46 \%$, urine by $74 \%$ and total bilirubin by $34 \%$.

When the liposomal preparation Butaselmevit was administered to rats suffering oxidative stress normalization of the activity of hematological processes in the blood took place in the course of the experiment; namely on the 14th day of the experiment the following indicators came within the frames of physiological values, number of erythrocytes, hemoglobin content, number of leucocytes and indexes of red blood in comparison with the control group, which indicates the restoration of hematopoietic function of the bone marrow. It will be worth conducting further research on leukograms of the blood of rats suffering oxidative stress and receiving a liposomal preparation.

\section{References}

Calabrese, E., Leonard, D., \& Xiaoqiang, Z. (1999). Role of tissue repair in carbon tetrachloride hepatotoxicity in male and female Sprague-Dawley and Wistar rats. International Journal of Toxicology, 15, 62-69.

Chen, W., Kennedy, D. O., Kojima, A., \& Matsui-Yuasa, I. (2000). Polyamines and thiols in the cytoprotective effect of L-cysteine and L-methionine on carbon tetrachloride-induced hepatotoxicity. Amino Acids, 18(4), 319-327.

Cherkashina, D. V., \& Petrenko, A. Y. (2006). Hepatoprotective effect of fetal tissue cytosol and its thermostable fraction in rats with carbon tetrachlorideinduced hepatitis. Bulletin of Experimental Biology and Medicine, 141(4), $544-547$.

Gutyj, B. V., Hufriy, D. F., Hunchak, V. M., Khariv, I. I., Levkivska, N. D., \& Huberuk, V. O. (2016). The influence of metisevit and metifen on the intensity of lipid per oxidation in the blood of bulls on nitrate load. Scientific Messenger LNUVMBT named after S. Z. Gzhytskyj, 18(3), 67-70. 
Gutyj, B. V., Murs'ka, S. D., Gufrij, D. F., Hariv, I. I., Levkivs'ka, N. D., Nazaruk, N. V., Gajdjuk, M. B., Pryjma, O. B., Bilyk, O. J., \& Guta, Z. A. (2016). Vplyv kadmiievoho navantazhennia na systemu antyoksydantnoho zakhystu orhanizmu buhaitsiv [Influence of cadmium loading on the state of the antioxidant system in the organism of bulls]. Visnyk of Dnipropetrovsk University. Biology, Ecology, 24(1), 96-102.

Gutyj, B., Khariv, I., Binkevych, V., Binkevych, O., Levkivska, N., Levkivskyj, D., \& Vavrysevich, Y. (2017). Research on acute and chronic toxity of the experimental drug Amprolinsyl. Regulatory Mechanisms in Biosystems, $8(1), 41-45$.

Gutyj, B., Lavryshyn, Y., Binkevych, V., Binkevych, O., Paladischuk, O., Strons'kyj, J., \& Hariv, I. (2016). Influence of "Metisevit" on the activity of enzyme and nonenzyme link of antioxidant protection under the bull's body cadmium loading. Scientific Messenger LNUVMBT named after S. Z. Gzhytskyj, 18(2), 52-58.

Gutyj, B., Paska, M., Levkivska, N., Pelenyo, R., Nazaruk, N., \& Guta, Z. (2016). Study of acute and chronic toxicity of 'injectable mevesel' investigational drug. Biological Bulletin of Bogdan Chmelnitskiy Melitopol State Pedagogical University, 6(2), 174-180.

Hariv, M. I., \& Gutyj, B. V. (2016). Vplyv liposomalnoho preparatu Butaintervit na proteinsyntezuvalnu funktsiiu pechinky shchuriv za otruiennia tetrakhlormetanom [Influence of the liposomal preparation Butaintervite on protein synthesis function in the livers of rats under the influence of carbon tetrachloride poisoning]. Visnyk of Dnipropetrovsk University. Biology, Medicine, 7(2), 123-126 (in Ukrainian).

Khariv, M., Gutyj, B., Butsyak, V., \& Khariv, I. (2016). Hematolohichni pokaznyky orhanizmu shchuriv za umov oksydatsiinoho stresu ta za dii liposomalnoho preparatu [Hematological indices of rat organisms under conditions of oxidative stress and liposomal preparation action]. Biological Bulletin of Bogdan Chmelnitskiy Melitopol State Pedagogical University, 6(1), 276-289 (in Ukrainian).

Lavryshyn, Y. Y., Varkholyak, I. S., Martyschuk, T. V., Guta, Z. A., Ivankiv, L. B., Paladischuk, O. R., Murska, S. D., Gutyj, B. V., \& Gufriy, D. F. (2016). The biological significance of the antioxidant defense system of animals' bodies. Scientific Messenger LNUVMBT named after S. Z. Gzhytskyj, 18(2), 100-111.

Li, D., Cai, H., Hou, M., \& Fu, D. (2012). Effects of indoleamine 2,3dioxygenases in carbon tetrachloride-induced hepatitis model of rats. Cell Biochemistry and Function, 30(4), 309-314.

Longo, V., Chirulli, V., Gervasi, P. G., Nencioni, S., \& Pellegrini, M. (2007). Lisosan G, a powder of grain, does not interfer with the drug metabolizing enzymes and has a protective role on carbon tetrachloride-induced hepatotoxicity. Biotechnology Letters, 29(8), 1155-1159.

Martyshuk, T. V., Gutyj, B. V., \& Vishchur, O. I. (2016). Riven produktiv perekysnoho okysnennia lipidiv u krovi shchuriv za umov oksydatsiinoho stresu ta za dii liposomalnoho preparatu "Butaselmevit" [Level of lipid peroxidation products in the blood of rats under the influence of oxidative stress and under the action of liposomal preparation of "Butaselmevit"]. Biological Bulletin of Bogdan Chmelnitskiy Melitopol State Pedagogical University, 6(2), 22-27 (in Ukrainian).

Sato, S., Dai, W., Liu, X.-L., \& Asano, G. (1999). The protective effect of hepatocyte growth-promoting factor (pHGF) against carbon tetrachlorideinduced acute liver injury in rats: An ultrastructural study. Medical Electron Microscopy, 32(3), 184-192.

Smolynets', I. B., Gutyj, B. V., Khariv, I. I., Petryshak, O. Y., \& Lytvyn, R. I. (2016). Pharmaceutical marketing: Objectives and types. Scientific Messenger LNUVMBT named after S. Z. Gzhytskyj, 18(2), 151-154.

Vlizlo, V. V. (2012). Laboratorni metody doslidzhen u biolohiyi, tvarynnytstvi ta veterynarniy medytsyni [Laboratory methods of investigation in biology, stock-breeding and veterinary]. Spolom, Lviv (in Ukrainian).

Vyshtakaliuk, A. B., Nazarov, N. G., Porfiriev, A. G., Zueva, I. V., Minnechanova, O. A., Mayatina, O. V., Reznik, V. S., Zobov, V. V., \& Nicolskyi, E. E. (2015). The influence of the Xymedon preparation (Hydroxyethyldimethyldihydropyrimidine) on the rat liver recovery under toxic damage induced by carbon tetrachloride. Biochemistry, Biophysics and Molecular Biology, 462(1), 143-146.

Wolf, P. L. (1999). Biochemical diagnosis of liver disease. Indian Journal of Clinical Biochemistry, 14(1), 59-90. 